\title{
Evidence that rifampicin can be used safely for non-tuberculous diseases
}

\author{
G ACOCELLA, W BRUMFITT, AND J M T HAMILTON-MILLER
}

From the Department of Medical Microbiology, Royal Free Hospital, London

ABSTRACT The incidence of primary resistance to rifampicin in Mycobacterium tuberculosis has been analysed in countries where rifampicin is restricted to use for treating tuberculosis and in countries where its use is not restricted. There is no evidence that rifampicin-resistant $M$ tuberculosisg strains are more common where the use of the drug is unrestricted. Resistance to rifampicin is lesscommon than is resistance to streptomycin or to isoniazid. We can thus see no danger of producing resistant strains of $M$ tuberculosis if rifampicin therapy is used for short periods for non-tuberculouso infections. The problem of resistant mutants arising in the non-tuberculous species being treated iș overcome by combining rifampicin with trimethoprim.

Rifampicin has a uniquely wide spectrum of antimicrobial activity, which includes Grampositive and Gram-negative organisms as well as Mycobacterium tuberculosis. ${ }^{1}$ Because of this, in a relatively early phase of the clinical use of this antibiotic for non-tuberculous indications, rifampicin was employed alone in infections of the chest $^{2}$ and urinary tract. ${ }^{34}$ However, the observation that in these circumstances resistant mutants were rapidly selected caused the use of monotherapy with rifampicin in non-tuberculous infections to fall into disrepute.

As a logical means of overcoming this problem, a combination of rifampicin and trimethoprim was envisaged, based on a "double blockade" type of approach. The basic assumptions were confirmed in a series of microbiological studies, ${ }^{56}$ which indicated both the existence of synergism between the two compounds and the prevention of the selection of resistant mutants. The situation concerning fears for the development of resistance in $M$ tuberculosis ${ }^{7}$ as a result of rifampicin/trimethoprim being used was summarised in a provocative editorial. ${ }^{8}$

Since then, the pharmacokinetic properties of the combination ${ }^{9} 10$ and its clinical effectiveness ${ }^{11}$ have been evaluated, and confirmed the encouraging preclinical evidence. A further and most important part of the development of the combination has been, and continues to be,

Address for reprint requests: Professor W Brumfitt, Department of Medical Microbiology, Royal Free Hospital, Pond Street, London NW3 2QG. devoted to the evaluation of possible risks con nected with the extra-tuberculous use of rifampicin.

We agree whole-heartedly with Simmons ${ }^{12}$ whon stated: "those who advocate that rifampicin should be used much more freely should surelye be certain that the risk of development of wide -3 spread rifampicin-resistant $M$ tuberculosis is no only small but virtually non-existent." We, there fore, decided to carry out a comparative study on primary resistance in $M$ tuberculosis to rifampicin in countries where the use of the antibiotic is restricted to tuberculosis, and in those where it is freely available for the treatment of both tuberculous and non-tuberculous infec 3 tions. ${ }^{13}$ Our results indicated that $M$ tuberculosis had remained uniformly sensitive to rifampicin? after several years of use in both groups of countries. The incidence of primary resistance to rifampicin was extremely low. It was lowe (although not significantly) than that observed to ethambutol and PAS (which are used only forv tuberculosis), and significantly lower than thaf observed to streptomycin and isoniazid.

In view of the importance of this information we have decided to update and to extend the survey. The new and old data are reported in the present communication.

\section{Method and sources}

Primary resistance was defined, detected, anc diagnosed as by Canetti et al. ${ }^{14}$ Data werê 
collected from countries and centres shown in tables 1 and 2, not only from the literature but also by personal communication with $\mathbf{a}$ number of acknowledged experts: Dr J Grosset (Paris), Dr FJ Guerra-Sanz and Dr OrtegaCalderon (Madrid), Dr M Tavares da Lima Filho (Sao Paulo), Dr GA Jaramillo (Bogota), Dr A Giobbi (Milan), and Dr M Lucchesi (Rome). In France, USA, and West Germany rifampicin is restricted for use in tuberculosis, while in the other countries in tables 1 and 2 it is freely available for the treatment of any infection.

\section{Results}

As is clear from table 1, the incidence of primary resistance to rifampicin is low and has not changed with time-hence, for practical purposes, it is a small clinical problem. From the data in table 2 it can be observed that much the same applies for the other major antitubercular drugs. Primary resistance has altered very little with time, and is relatively low in absolute terms.

\section{Discussion}

As in the previous survey, the level of sensitivity is similar in countries like France, where rifampicin is used only for tuberculosis, and Colombia, where the ratio of non-tubercular to tubercular use of the antibiotic is of the order of 9:1.

In agreement with the previous observations, the very few cases of acquired resistance to rifampicin were found to be associated with the improper use of the drug in tuberculous patients, including cases of monotherapy. The latter observation is important, since it is well known that cases of bacteriological failure observed during combined antituberculosis regimens can occur with strains which are still sensitive to rifampicin. ${ }^{30}$

It can, therefore, be concluded that treatment of non-tuberculous infections with rifampicin for short periods does not carry a risk of selecting rifampicin-resistant strains of $M$ tuberculosis. Thus, the proposed use of the combination rifampicin-trimethoprim for periods of one week in non-tuberculous indications should in no way jeopardise the antituberculous efficacy of rifampicin.

\section{References}

1 Binda G, Domenichini E, Gottardi A et al. Rifampicin: a general review. Arzneim Forsch 1971; 21:1907-77.

2 Citron KM, May JR. Rifamycin antibiotics in chronic purulent bronchitis. Lancet 1969; 2:982-3.

3 Atlas E, Turck M. Laboratory and clinical evaluation of rifampicin. Am J Med Sci 1968; 256:247-54.

4 Murdoch J McC, Speirs CF, Wright N, Wallace ET. Rifampicin. Lancet 1969; 1:1094.

5 Kerry DW, Hamilton-Miller JMT, Brumfitt W. Trimethoprim and rifampicin: in vitro activities separately and in combination. J Antimicrob Chemother 1975; 1:417-27.

Table 1 Percentage of strains of $M$ tuberculosis found primarily resistant to rifampicin in the years $1969-78$ in numerous different geographical locations

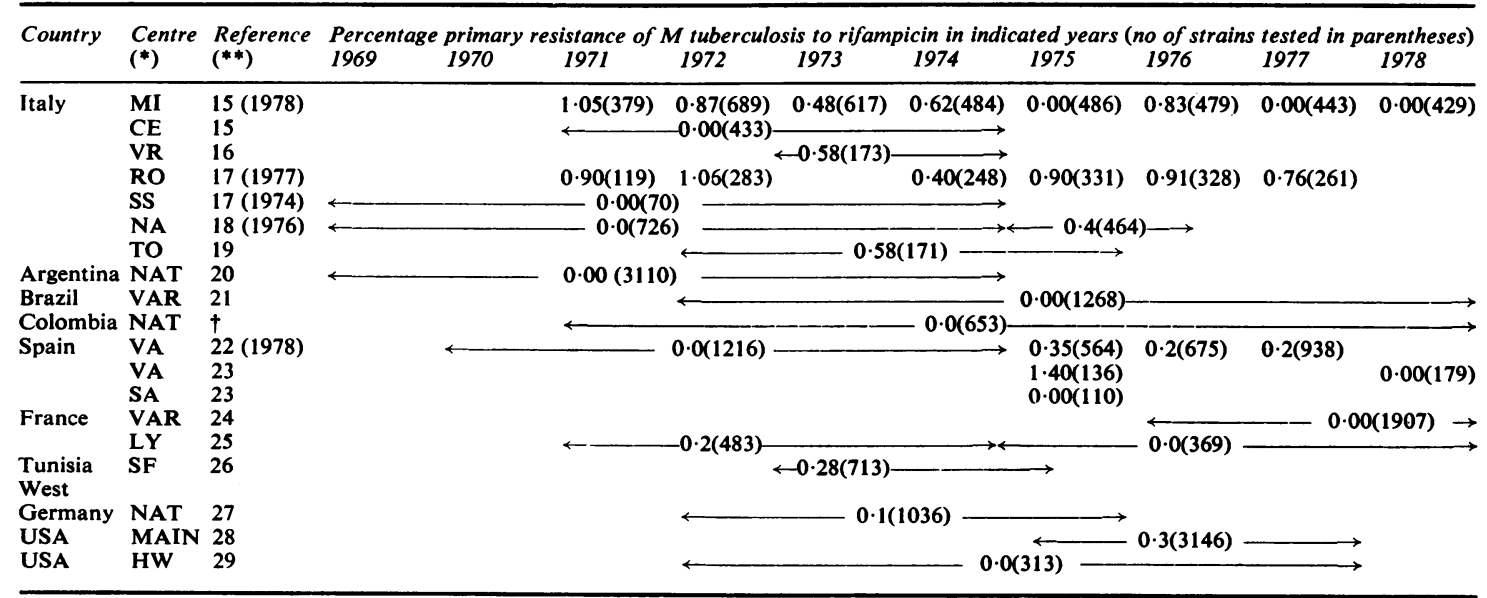

(*) MI = Milan; GE = Genoa; VR = Verona RO = Rome; SS = Sassari; NA = Naples; TO = Turin; NAT = National; VAR = Various VA $=$ Valencia; MA = Madrid; SA = Salamanca; LY $=$ Lyon; SF $=$ Sfax; MAIN $=$ Mainland; HW $=$ Hawaii. (**) Year quoted in parentheses indicates year of last updating completed (generally unpublished). 
6 Arioli V, Berti M, Carniti G, Rossi E, Silvestri LG. Interaction between rifampicin and trimethoprim in vitro and in experimental infections. J Antimicrob Chemother 1977; 3:87-94.

7 Morrison-Smith J. Rifampicin in clinical use. J Antimicrob Chemother 1976; 2:353-4.

8 Editorial. Rifampicin: for tuberculosis only? Lancet 1976; 1:290-1.

9 Acocella G, Scotti R. Kinetic studies on the combination rifampicin-trimethoprim in man. I. Absorption and urinary excretion after administration to healthy volunteers of single doses of $\mathrm{G}$ the two compounds alone and in combination $\vec{\theta}$ over a period of one week. J Antimicrob Chemother 1976; 2:271-7.

10 Hamilton-Miller JMT, Brumfitt W. Trimethoprim and rifampicin: pharmacokinetic studies in man. J Antimicrob Chemother 1976; 2:181-8.

11 Brumfitt W, Cooper J, Hamilton-Miller JMT. O Rifaprim (rifampicin and trimethoprim): a com- ${ }^{\circ}$ parative trial with cephradine in patients with $\mathbb{\Phi}$ recurrent urinary infections. Proceedings of the 11th International Congress of Chemotherapy $ळ$ 1980 ; in press

12 Simmons NA. Synergy and rifampicin. J Antimicrob Chemother 1977; 3:109-11.

13 Acocella G, Hamilton-Miller JMT, Brumfitt W. Can rifampicin use be safely extended? Evidence for non-emergence of resistant strains of $\frac{\varnothing}{\varnothing}$ Mycobacterium tuberculosis. Lancet 1977; 1: 740-2.

14 Canetti G, Fox W, Khomenko A et al. Э Advances in techniques of testing mycobacterial $\supset$ drug sensitivity, and the use of sensitivity tests in tuberculosis control programmes. Bull $\mathrm{WHO}$ 1969; 41:21-43.

15 Giobbi A, Bulgheroni P, Mantellini P, Miradoli E, Pandiani C. Osservazioni sulla batteriologia $\times$ della tuberculosi dopo rifampicina. Riv Inst Vaccin Milano 1975; 25:323-31.

16 Longarato-Jacometta F, Zambelli L. Osservazioni sul comportamento della resistenza batterica c.d. primaria in malati di tubercolosi polmonare di 윽 primo accertamento. Friuli Med 1975; 30:681-90.

17 Lucchesi M, Zubiani M, Bajocco M, Ginesu F. 을 Ulteriore contributo sulla resistenza primaria del Mycobacterium tuberculosis ai chemioantibioticio specifici. Lotta contro tubercolosi Malattie Pol-N monari Sociali 1975; 45:1-8.

18 Nitti V. La resistenza primaria del microbatterio tubercolare. Aspetti batteriologici ed epidemiologici. Arch Monaldi 1972; 27:454-74.

19 Briccarello L, Bardessono F, Daglio C, Ferrano U, Giorgis GE, Maschini MT. Il fenomeno della resistenza primaria del bacillo di Koch: casistica raccolta nell'Ospedale Pneumologico San Luigi di Torino dal 1972 al 1975. G Batteriol Virol Immunol 1976; 69:49-59.

20 Amadio GE. Evolucion de los indices de resistencia bacteriana en tuberculosis en la Republica Argentina. Arch Monaldi 1977; 32:12-17. 
21 Tavares da Lima Filho M. A resistencia bacilar primaria dos drogas no Brasil en especial na cidade de Sao Paulo. Proceedings of the 5th International Symposium on Chemotherapy of Tuberculosis, Madrid, 1976.

22 Ortega-Calderon A, March Arbos J. Evolucion de la resistencia primaria del Mycobacterium tuberculosis en los ultimos 5 años (1970-1976). Arch Monaldi 1977; 32:1-11.

23 Garcia JA, Saenz MC, Prieto J, Martin F. Incidence of drug resistance on the mycobacterial strains isolated from treated and untreated patients. In: Williams JD, Geddes AM, eds. Proceedings of the 9th International Congress of Chemotherapy. New York: Plenum Press, 1976: 3:81-6.

24 Grosset J. Bacteriological basis of the chemotherapy of tuberculosis. PAHO Regional Seminar on Tuberculosis: Chemotherapy. Washington DC: Pan American Health Organisation, 1979.

25 Viallier J. La recherche de la sensibilité aux antibiotiques du bacille tuberculeux: est-elle toujours nécessaire pour la conduite correcte du traitement? Lyon Med 1978; 240:425-6.
26 Najah S, Tchekel I. Étude de la résistance du bacille tuberculeux dans la region de Sfax, durant les années 1973 a 1975. Rev Franc Malad Respir 1978; 6:179-82.

27 Hussels H, Matthiessen W, Kind A, Göbel D. Frequency and epidemiology of primary drug resistance in tuberculosis in the Federal Republic of Germany, including Berlin (West). Partial result of a study of the WATL. Scand $J$ Respir Dis 1978; supplement 102:65-7.

28 Kopanoff DE, Kilburn JO, Glassroth JL, Snider DE, Farer LS, Good RC. A continuing survey of tuberculosis primary drug resistance in the United States: March 1975 to November 1977. Am Rev Respir Dis 1978; 118:835-442.

29 Pien FD, Michael NL, Ow CL, Vennesland K, Brodsky ML. Primary antituberculous drug resistance in Hawaii, 1957 to 1977. Am Rev Respir Dis 1978; 118:701-4.

30 Medical Research Council. Co-operative controlled trial of a standard regimen of streptomycin, PAS and isoniazid and three alternative regimens of chemotherapy in Britain. Tubercle 1973 ; 54:99-129. 